\title{
Cervical cancer: incidence and survival in migrants within Spain
}

\author{
Josep M Borràs, Victoria Sánchez, Victor Moreno, Angel Izquierdo, Pau Viladiu
}

\begin{abstract}
Study objective - This study examined the incidence of cervical cancer and survival rates according to migrant experience of women from different regions of Spain to Girona, Catalonia (Spain).

Design - Using data from the population based cancer registry of Girona for the period $1980-89$, crude and age adjusted incidence rates were calculated for localborn and first generation migrants from other Spanish regions. The age standardised rate ratio (SRR) was calculated and Cox's regression model was used to adjust survival according to migrant status for age and stage at diagnosis.

Main results - The incidence of cervical cancer was significantly higher in first generation Spanish migrants compared with locally born women (SRR: 2.02; 95\% CI $1 \cdot 40: 2 \cdot 92)$. The stage at diagnosis was more advanced among migrants. Survival probability was significantly associated with stage at diagnosis, but age and region of birth were not.

Conclusions - Migrants from the southern Spanish regions show a twofold excess in the incidence of cervical cancer compared with the Girona-born female population. Cases of cervical cancer in migrants are diagnosed at a more advanced stage and as a consequence have a poorer prognosis.
\end{abstract}

(f Epidemiol Community Health 1995;49:153-157)

Department of Health and Social Security, Generalitat de

Catalunya,

Pavello Ave Maria,

Trav Corts 131-159,

08028 Barcelona, Spain

$\mathrm{J} M$ Borràs

V Sánchez

Cancer Registry of

Girona, Spain

A Izquierdo

$P$ Viladiu

Department of Preventive Medicine

(Biostatistics),

Autonomous

University of

Barcelona, Spain

V Moreno

Catalan Institute of Oncology, Barcelona, Spain

P Viladiu

Correspondence to: Dr J M Borràs

Accepted for publication June 1994
Studies of the pattern of cancer incidence or mortality among migrant populations are a useful tool for exploring the aetiology of cancer, especially with regard to the possible role of genetic, lifestyle, and environmental factors. ${ }^{12}$ These studies have generally compared the occurrence of the disease in migrants from very different cultural or even ethnic backgrounds for instance, Japanese migrants to the USA ${ }^{3}$ and Brazil, ${ }^{4}$ or Italian migrants in other countries. ${ }^{5}$ Different patterns of mortality or incidence are found in these studies in cancers of the stomach, breast, cervix, colon-rectum, and others. Few of these studies, however, have analysed differences in cancer risk in those who migrate within one country. ${ }^{6-9}$

Cervical cancer shows an important international variation in its incidence. ${ }^{10}$ Several risk factors have been related to this cancer. Some of the established ones are consistent with the presence of a sexually transmitted aetiologic agent; in fact, in recent years, a strong association between human papilloma virus (HPV) and cervical cancer has been established. ${ }^{11} 12$ Other associated risk factors, such as the number of partners (both of the woman and of her partner(s)) and the age at first intercourse, could be surrogates of HPV infection. Oral contraceptives, smoking, and some dietary factors are also risk factors that have been associated with cervical cancer.

Spain has one of the lowest incidences of cervical cancer, as observed by the country's various cancer registries. ${ }^{1314}$ Intense internal migration has traditionally occurred between regions of Spain. The region of Catalonia and the city of Madrid have been the recipients of most of this migration throughout this century. In fact, $34 \cdot 1 \%$ of people living in Catalonia today were born in another region of Spain. ${ }^{15}$

This study aimed to examine the incidence and survival associated with cervical cancer in first generation migrants to Girona (Catalonia, Spain) from other Spanish regions using data from a population based cancer registry.

\section{Methods}

Data from the population based cancer registry of Girona covering the period 1980-89 were used. Girona is a province of Catalonia in north eastern Spain, with a female population of 246515 in 1986, of whom $24 \%$ were born outside the province. Of the female population, $68.3 \%$ were born in Girona, $7 \cdot 7 \%$ in other provinces of Catalonia, $15.2 \%$ in AndaluciaExtremadura (southern regions of Spain), 6.6\% in other regions of Spain, and $2 \cdot 2 \%$ abroad. ${ }^{16}$

The population based cancer registry of $\mathrm{Gi}-$ rona is restricted to cancer of the breast, uterus, ovary, and other genitals. It actively collects information on all incident cases among the residents in the province of Girona. Quality indices regarding cervical cancer were as follows: $98.3 \%$ of histological verification and $1 \%$ of cases were identified by death certificate only. Cancer cases are classified according to the ICD-O (9th revision). The cancer registry provided information on the patient's age, tumour site, stage of the disease (divided into local, regional and disseminated), and follow up status. The registry includes cases since January 1980: all cases were followed up actively and passively (through death certificates) until December 1991. Cancers in situ were included in the registry, but only presented for descriptive purposes. Place of birth is routinely collected, and has been used to identify first generation migrants. The year of migration is not available.

Rates were initially calculated by grouping the cases into two periods $1980-84$ and $1985-$ 
Table 1 Incidence rates of invasive cervical cancer 1980-89

\begin{tabular}{|c|c|c|c|c|c|c|c|c|c|c|c|}
\hline \multirow{2}{*}{ Region } & \multicolumn{7}{|c|}{ Age group (y) } & \multirow{2}{*}{ Crude rate } & \multirow{2}{*}{$\begin{array}{l}\text { Age standardised } \\
\text { rate* }^{*}\end{array}$} & \multirow{2}{*}{$\begin{array}{l}\text { Standard } \\
\text { error }\end{array}$} & \multirow{2}{*}{ No } \\
\hline & $0-$ & $15-$ & $35-$ & $45-$ & $55-$ & $65-$ & $75+$ & & & & \\
\hline $\begin{array}{l}\text { Gerona (Catalonia) } \\
\text { South of Spain } \\
\text { Rest of Spain } \\
\text { Born in other countries } \\
\text { Spanish migrants } \dagger \\
\text { Total }\end{array}$ & $\begin{array}{l}0 \cdot 00 \\
0 \cdot 00 \\
0 \cdot 00 \\
0 \cdot 00 \\
0 \cdot 00 \\
0 \cdot 00\end{array}$ & $\begin{array}{l}1 \cdot 86 \\
1 \cdot 68 \\
2 \cdot 28 \\
5 \cdot 33 \\
1 \cdot 84 \\
2 \cdot 25\end{array}$ & $\begin{array}{r}7 \cdot 42 \\
7 \cdot 04 \\
11 \cdot 41 \\
23 \cdot 64 \\
8 \cdot 22 \\
9 \cdot 70\end{array}$ & $\begin{array}{r}8 \cdot 89 \\
31 \cdot 12 \\
8 \cdot 50 \\
17 \cdot 21 \\
24 \cdot 58 \\
15 \cdot 51\end{array}$ & $\begin{array}{l}11 \cdot 58 \\
30 \cdot 88 \\
22 \cdot 15 \\
69 \cdot 44 \\
27 \cdot 98 \\
17 \cdot 41\end{array}$ & $\begin{array}{r}14 \cdot 79 \\
24 \cdot 62 \\
48 \cdot 78 \\
0 \cdot 00 \\
33 \cdot 57 \\
19 \cdot 15\end{array}$ & $\begin{array}{r}8 \cdot 76 \\
20 \cdot 01 \\
30 \cdot 61 \\
57 \cdot 14 \\
24 \cdot 20 \\
14 \cdot 45\end{array}$ & $\begin{array}{r}5 \cdot 34 \\
13 \cdot 96 \\
13 \cdot 97 \\
18 \cdot 04 \\
13 \cdot 96 \\
8 \cdot 19\end{array}$ & $\begin{array}{r}4 \cdot 29 \\
8 \cdot 89 \\
7 \cdot 83 \\
13 \cdot 08 \\
8 \cdot 66 \\
6 \cdot 21\end{array}$ & $\begin{array}{l}0.49 \\
1 \cdot 29 \\
1 \cdot 78 \\
4 \cdot 40 \\
1 \cdot 06 \\
0 \cdot 48\end{array}$ & $\begin{array}{r}92 \\
48 \\
21 \\
9 \\
69 \\
180\end{array}$ \\
\hline
\end{tabular}

*World standard population.

tIncluding south of Spain and rest of Spain

Including south of Spain and rest of Spain;
łincluding 10 cases with region of birth unknown.

89. The results were highly consistent, and results for the entire period (1980-89) are therefore presented. Age adjustment of the rates was performed by the direct method and using the world standard population. Migrants were classified according to region of birth as follows: born in Girona and in other parts of Catalonia, born in the south of Spain (including Andalusia and Extremadura), born in other regions of Spain, and born in other countries.

Comparison of the age standardised incidence rates was done using the standardised rate ratio (SRR) and $95 \%$ confidence interval $(95 \% \mathrm{CI}) .{ }^{17} \mathrm{SRR}$ is the ratio between two directly age adjusted rates and is equivalent to the relative risk of disease in migrant population compared to local born population.

It is possible to calculate the statistical significance of the SRR as an indication of whether the observed ratio is significantly different from unity.

Differences in the stage at diagnosis according to region of birth were analysed by the $\chi^{2}$ statistic. Survival was analysed first by region of birth, using the Kaplan-Meier estimate. To compare the probabilities of survival according to the region of birth, the log rank test was used. To adjust for differences in the stage at diagnosis or age on the relationship between region of birth and survival, Cox's proportional hazard model was used. ${ }^{18}$ The following variables were included in the model: age at diagnosis, region of birth, and stage at diagnosis. Age was divided into the following groups: less than 34, 34-45, 45-54, 55-64, and 65 and over. The reference categories used for the analysis were as follows: age group was less than 35 years, stage at diagnosis local, and

Table 2 Standardised rate ratio (SRR) of invasive cervical cancer 1980-89

\begin{tabular}{lll}
\hline Region & $S R R$ & $(95 \%$ CI $)$ \\
\hline Spanish migrants*/Gerona & 2.02 & $(1.40,2.92)$ \\
South of Spain/Gerona & $2 \cdot 07$ & $(1.35,3.19)$ \\
Rest of Spain/Gerona & 1.83 & $(0.99,3.38)$ \\
\hline
\end{tabular}

*Including south of Spain and rest of Spain region of birth Catalonia. Hazards proportionality assumption of Cox's model was checked through including the log survival function against time in the model. Computations were performed using EGRET software. ${ }^{19}$

\section{Results}

There were 180 women diagnosed with invasive cervical cancer in Girona, Catalonia, during the period 1980-89. The crude annual incidence rate is 8.19 per 100000 women and the age adjusted rate is 6.21 per 100000 women. The region of birth was unknown in 10 cases, so 170 cases only are included in the study. Crude, age specific, and age adjusted incidence rates are shown in table 1 according to the region of birth for the period 1980-89. The age adjusted rates in women born in southern regions of Spain and the rest of Spain are approximately twice those of the Girona born women in the study period. The age adjusted incidence rate of women born abroad is the highest, probably as a result of subregistration in the denominator. Part of the at risk group that was born outside of Spain is still included in the census of their country of origin. This group was consequently excluded from the rest of the analyses. The age specific incidence rates by region of birth (table 1) show a consistently higher incidence rate in migrants of age groups of 45 and older compared with the rates in Catalan born women. In addition, the rate for women born in the rest of Spain and abroad shows a higher rate even in younger age groups, but few cases are involved.

The SRR comparing incidence rates of Spanish migrants versus those born in Girona was 2.02 (95\% CI 1.40, 2.92). The SRR was higher in women from southern regions of Spain versus those born in Girona than in other Spanish regions versus Girona (table 2).

The stage distribution at the time of diagnosis, including cervical cancer in situ, is shown in table 3 in relation to the region of birth.

Table 3 Stage at diagnosis in relation to region of birth 1980-89

\begin{tabular}{|c|c|c|c|c|c|c|c|c|c|c|c|}
\hline \multirow[t]{2}{*}{ Stage } & \multicolumn{2}{|c|}{ Gerona } & \multicolumn{2}{|c|}{ South of } & \multirow{2}{*}{$\begin{array}{l}\text { Rest of } \\
\text { Spain } \\
\text { No }\end{array}$} & \multirow[b]{2}{*}{$(\%)$} & \multicolumn{2}{|c|}{$\begin{array}{l}\text { Other } \\
\text { countries }\end{array}$} & \multicolumn{3}{|c|}{ Unknown } \\
\hline & No & $(\%)$ & No & $(\%)$ & & & No & $(\%)$ & No & $(\%)$ & No \\
\hline 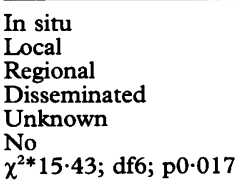 & $\begin{array}{r}46 \\
36 \\
26 \\
24 \\
6 \\
138\end{array}$ & $\begin{array}{r}(33 \cdot 33) \\
(26 \cdot 09) \\
(18 \cdot 84) \\
(17.39) \\
(4 \cdot 35) \\
(100 \cdot 00)\end{array}$ & $\begin{array}{r}9 \\
13 \\
20 \\
15 \\
0 \\
57\end{array}$ & $\begin{array}{r}(15 \cdot 79) \\
(22 \cdot 81) \\
(35 \cdot 09) \\
(26 \cdot 32) \\
(0 \cdot 00) \\
(100 \cdot 00)\end{array}$ & $\begin{array}{r}7 \\
4 \\
12 \\
4 \\
1 \\
28\end{array}$ & $\begin{array}{r}(25 \cdot 00) \\
(14 \cdot 29) \\
(42 \cdot 86) \\
(14 \cdot 29) \\
(3 \cdot 57) \\
(100 \cdot 00)\end{array}$ & $\begin{array}{r}9 \\
8 \\
1 \\
0 \\
0 \\
18\end{array}$ & $\begin{array}{r}(50.00) \\
(44.44) \\
(5.56) \\
(0.00) \\
(0.00) \\
(100.00)\end{array}$ & $\begin{array}{r}18 \\
4 \\
2 \\
0 \\
4 \\
28\end{array}$ & $\begin{array}{r}(64 \cdot 29) \\
(14 \cdot 29) \\
(7 \cdot 14) \\
(0 \cdot 00) \\
(14 \cdot 29) \\
(100 \cdot 00)\end{array}$ & $\begin{array}{r}89 \\
65 \\
61 \\
43 \\
11 \\
269\end{array}$ \\
\hline
\end{tabular}

*Excluding stage at diagnosis unknown, region of birth unknown, and born in other countries. 
Table 4 Probability of survival at one and five years in relation to stage at diagnosis, region of birth, and age

\begin{tabular}{lllll}
\hline & $1 y$ & $5 y$ & $\log$ rank & $p$ \\
\hline Local & 0.932 & 0.643 & & \\
Regional & 0.828 & 0.403 & & \\
Disseminated & 0.626 & 0.214 & & \\
Unknown & 0.800 & 0.300 & 30.02 & $<0.000$ \\
Catalonia & 0.919 & 0.414 & & \\
South of Spain & 0.729 & 0.432 & & \\
Rest of Spain & 0.950 & 0.364 & 0.43 & 0.808 \\
Age (y): & & & & \\
$\quad$ 0-34 & 0.909 & 0.582 & & \\
35-44 & 0.773 & 0.578 & & \\
45-54 & 0.800 & 0.326 & & \\
55-64 & 0.800 & 0.504 & & \\
\hline
\end{tabular}

Table 5 Cox's proportional hazards survival analysis in relation to stage at diagnosis, region of birth, and age

\begin{tabular}{|c|c|c|c|}
\hline & Hazard ratio & $(95 \% C I)$ & $p$ \\
\hline $\begin{array}{l}\text { Local } \\
\text { Regional } \\
\text { Disseminated } \\
\text { Unknown }\end{array}$ & $\begin{array}{l}1 \\
2 \cdot 134 \\
4 \cdot 334 \\
2 \cdot 689\end{array}$ & $\begin{array}{l}(1 \cdot 134,4 \cdot 016) \\
(2 \cdot 367,7.936) \\
(0 \cdot 749,9.649)\end{array}$ & $\begin{array}{r}0 \cdot 190 \\
<0 \cdot 001 \\
0 \cdot 129\end{array}$ \\
\hline $\begin{array}{l}\text { Catalonia } \\
\text { South of Spain } \\
\text { Rest of Spain }\end{array}$ & $\begin{array}{l}1 \\
0 \cdot 831 \\
0.678\end{array}$ & $\begin{array}{l}(0.499,1.386) \\
(0.327,1.402)\end{array}$ & $\begin{array}{l}0 \cdot 479 \\
0 \cdot 249\end{array}$ \\
\hline $\begin{array}{c}\text { Age }(y) \\
0-34 \\
35-44 \\
45-54 \\
55-64 \\
65+\end{array}$ & $\begin{array}{l}1 \\
1 \cdot 172 \\
1 \cdot 639 \\
1 \cdot 132 \\
1 \cdot 382\end{array}$ & $\begin{array}{l}(0.365,3.768) \\
(0.542,4.953) \\
(0.376,3.405) \\
(0.474,4.029)\end{array}$ & $\begin{array}{l}0 \cdot 790 \\
0 \cdot 381 \\
0 \cdot 825 \\
0.554\end{array}$ \\
\hline
\end{tabular}

Migrants tend to have a higher proportion of women diagnosed at a later stage than women born in Girona and conversely, the proportion of cancer diagnosed at the "in situ" stage is significantly lower among migrant women.

The probability of survival was significantly related to the stage at diagnosis $(p<0.0001)$ but neither the age $(p=0.655)$ nor the region of birth $(p=0.808)$ were significantly related to the probability of survival in univariant analysis (table 4). Because of the relationship between the stage at diagnosis and region of birth, a Cox's regression analysis was performed to compare survival between migrants and local born women, controlling for stage at diagnosis and age. Taking into account the age distribution and stage at diagnosis, the probability of survival was not significantly different in those born in Girona compared with women born in the southern regions or in the rest of Spain (table 5).

\section{Discussion}

A higher risk of developing invasive cervical cancer has been observed in women who migrated from several regions of Spain to Girona. In addition, this increased incidence was shown to be accompanied by a more advanced stage at diagnosis for migrants compared with women born in Girona. Survival was not significantly different according to the region of birth.

Some potential sources of bias should be taken into account when analysing these data. Some women might have migrated to search for medical care or social support after diagnosis, ${ }^{20}$ especially mothers or other family members of people who had previously migrated. These women might have become residents only for purposes of treatment. This bias could affect the population denominator because these women may not have been included in the census. It is unlikely, however, that, once included, this very small number of cases in the population denominator could influence the incidence rates in a specific direction. Migration to Girona to search for treatment should be of little relevance if we take into account the proximity $(100 \mathrm{~km})$ of Barcelona, where there are five university hospitals and where treatment could be obtained more easily than in Girona.

Ascertainment of cases through histological verification and coverage of the registry with regard to cervical cancer are comparable with other registries. ${ }^{1013}$ It should be noted that in $8.6 \%$ of cases it was not possible to ascertain the region of birth. The true distribution of place of birth in cases with an unknown place of birth tends to over-represent migrant patients, who are more likely to escape information retrieval procedures; in this case our findings of a twofold higher incidence among migrants should be viewed as an underestimation of the true incidence excess. If, in contrast, the cases of unknown place of birth were all local born, the analysis presented in tables 1 and 2 would still show a statistically significant excess among migrants. In our study, it was not possible to control for the length of stay in Girona or the age at migration. The former is an important variable in migrant studies, ${ }^{221}$ the latter is relevant in cervical cancer because of the established association with age at first intercourse and number of sexual partners, two variables likely to differ in relation to social class and place of residence.

The higher incidence of invasive cervical cancer among migrant women in Girona could be accounted for by two complementary factors: differential exposure to risk factors for cervical cancer and differential participation rate in screening activities. With regard to the first factor, the higher incidence could be partly explained by low socioeconomic status or lifestyles specific to migrant populations. Migrants are usually young people, and this population has shown different nuptial and fecundity rates but these rates are not independent of age in our country, ${ }^{223}$ so adjusting by age could account for this difference. Cervical cancer has been related to lower socioeconomic status in different countries ${ }^{2425}$ as well as in Spain. ${ }^{26}$ Migrants to Catalonia tend to have a lower socioeconomic level than the local born population; ${ }^{27}$ for example, the percentage of residents in Girona who have not completed primary school is $36.6 \%$ among Catalan born women and $43.1 \%$ among people not born in Girona. ${ }^{28}$ From this point of view, migration could be considered a surrogate for socioeconomic level, especially in first generation migrants. It has been suggested that social class could have an effect on the risk of cervical cancer independent of sexual behaviour, ${ }^{25}$ in fact the relationship between sexual behaviour and social class is unclear. ${ }^{29}$ Our results suggest that internal migration could be related to a different risk of cervical cancer, but the relationship with sexual behaviour is unknown.

It is probable that socioeconomic differences are related to an increased risk of cervical cancer. 
The second suggested explanation for these results is the lower rate of participation in cervical cancer screening. Screening for cervical cancer effectively reduces the incidence among those who participate for at least 10 years after a negative test. ${ }^{30}$ Screening is not centrally organised in Catalonia, it is a byproduct of gynaecological health care, largely private, and in many cases supported by social security. Data from a survey undertaken in the municipality of Girona and its surroundings ${ }^{31}$ indicate that the cervical cytology rate of migrants is lower than that of local born women $(30.7 \%$ and $23.4 \%$ respectively) and a strong relationship between educational level and self reported cervical screening was observed. Other authors have suggested that women from lower socioeconomic groups are less likely to have a screening test. ${ }^{32}$ This is partly supported by the significant difference in the proportions of cancers "in situ" found in relation to the region of birth (table 3 ). In fact, cancer in situ is largely a surrogate for screening practices. The possibility of uncompleted registration of in situ cancers makes any conclusion regarding these data provisional. The length of stay of the migrant population, a variable not available in our study, has been related to the observed reduction in the risk of invasive cancer in Israel, ${ }^{33}{ }^{34}$ where the trend also differed in relation to the place of birth of the migrants. The suggested explanation for this observation lies on the cumulative exposure to cytological screening in migrants after arriving in Israel. In conclusion, cytological screening could play a major role in explaining the difference in the incidence of invasive cervical cancer among migrants to Girona.

In this context, it is remarkable that differences in the cervical cancer incidence in relation to the region of birth do not suggest a difference in prognosis. This observation could indicate that the main problem of equity in health care detected in our study is one of accessibility to screening and not of the quality of treatment. ${ }^{35}$ This finding is consistent with other authors who have found little effect of socioeconomic differences on survival for this type of cancer, ${ }^{3637}$ and who pointed to equity of access to treatment as the main explanation for this finding.

Migrant studies are a useful tool for describing the epidemiology of a disease in a geographical area. Girona, like other regions of Spain, is an area with a low incidence of cervical cancer and one in which there is a twofold higher incidence rate in migrants than in native born women. The cancer stage at diagnosis is more advanced in migrants but survival is not significantly different in relation to the region of birth. The main reason for the higher incidence seems to lie in limited access to screening among migrants. It is possible that the differences observed in this first generation of migrants will disappear with time and in second generation migrants. Further research is needed to interpret fully these results. In particular, reasons for differences in the distribution of stage at diagnosis and access to screening practices should be addressed.
The authors would like to thank Drs F X Bosch and $S$ de Sanjosé for comments on a previous version of this manuscript, and to C Campillo and L Stonnaker for their editorial help.

1 Haenszel W. Migrant studies. In: Schottenfeld D, Fraumeni JF, eds. Cancer epidemiology and prevention. Philadelphia: WB Saunders, 1982:194-207.

2 Parkin DM. Studies of cancer in migrant populations: methods and interpretation. Rev Epidemiol Santé Publique 1992; 40:410-24.

3 Haenzsel W, Kurihara M. Studies of Japanese migrants. I. Mortality from cancer and other diseases among Japanese in the United States. F Natl Cancer Inst 1968;40:43-68.

4 Tsugana $T$, de Souza J, Costa $M$, et al. Cancer incidence rates among Japanese immigrants in the city of Sao Paulo, Brazil 1969-78. Cancer Causes Control 1990;1:189-93.

5 Geddes M, Balzi D, Buiatti E, Khalt M, Parkin D. Cancer in the Italian migrants. Cancer Causes Control 1991;2: $133-40$.

6 Kliewer EV. Influence of migrants on regional variations of stomach and colon cancer mortality in the western United States. Int $\mathcal{F}$ Epidemiol 1992;21:442-9.

7 Buiatti E, Geddes M, Kriebel D, Santucci M, Biggeri A. A case-control study of lung cancer in Florence, Italy. II Effect of migration from the south. $\mathcal{f}$ Epidemiol Community Effect of migration from

8 Merletti F, Rosso S, Terracini D, Cappa APM. Cancer of the breast in women born in southern Italy and who migrated to the city of Torino. Tumori 1987;73:229-32.

9 Vigotti MA, Cislaghi C, Balzi D, et al. Cancer mortality in migrant populations within Italy. Tumori 1988;74:107-28.

10 Parkin DM, Muir C, Whelan S, et al, eds. Cancer incidence in five continents. Vol VI. Lyon: International Agency for Research on Cancer, 1992.

11 Bosch FX, Muñoz N, Shah KV, Meheus A. Second international workshop on the epidemiology of cervical cancer and human papilloma virus. Int $\mathcal{f}$ Cancer 1992.52. 171-3.

12 Muñoz N, Bosch FX. HPV and cervical cancer: review of case-control and cohort studies. In: Muñoz N, Bosch FX, Shah KV, Meheus A, eds. The epidemiology of human papillomavirus and cervical cancer. Lyons: of human papillomavirus and cervical cancer. Lyons: Internation $251-63$.

13 González J, Gorgojo L, Martin J, Villar F, eds. Cáncer en España. Madrid: Ministerio de Sanidad y Consumo, 1993.

14 Borràs J. La incidència del càncer a Tarragona, 1980-89. Barcelona: Universitat Autonoma de Barcelona, 1993. MD thesis.

15 Pujadas I, Mendizabal E. La poblacio de Catalunya, 1975-86. Barcelona: Department de Politica Territorial, 1991.

16 Institut d'Estadistica de Catalunya. Dades del Padro de 1986. Barcelona: Institut d'Estadistica de Catalunya, 1990.

17 Boyle P, Parkin DM. Statistical methods for registries. In: Jensen OM, Parkin DM, Maclennan R, Muir CS, Skeet RG, eds. Cancer registration: principles and methods. Lyons: RG, eds. Cancer registrat

18 Cox DR. Regression models and life tables. Fournal of the Royal Statistical Society 1972;34:187-202.

19 SERC. EGRET. Seattle: Statistics and Epidemiology Research Corporation, 1993.

20 Bentham G. Migration and morbidity: implications for geographical studies of disease. Soc Sci Med 1988;26:49-54. $1 \mathrm{Kasl}$ SV, Berkman L. Health consequences of the experience of migration. Ann Rev Public Health 1983;4:69-90.

22 Recolons LL. Les migracions a Catalunya en un nou periode demografic. In: Rotger JM. Visio de Catalunya, una perspectiva sociologica. Barcelona: Diputacio de Barcelona, 1988:257-301.

23 Sarrible G. Poblacion y desigualdad social. Madrid: Centro de Investigaciones Sociologicas 1991:48-99.

24 Baquet CR, Horm JM, Gibbs T, Greenwald P. Socioeconomic factors and cancer incidence among blacks and economic factors and cancer incidence am
whites. $\mathcal{F}$ Natl Cancer Inst 1991;83:551-7.

25 Murphy MFG, Mant DCA, Goldblatt PO. Social class, marital status and cancer of uterine cervix in England and marital status and cancer of uterine cervix in England and
Wales 1950-1983. F Epidemiol Community Health 1992; Wales 1950-1.

26 Bosch FX, Muñoz N, de Sanjosé S, et al. Risk factors for cervical cancer in Colombia and Spain. Int $\mathcal{F}$ Cancer 1992; 52:750-8.

27 Miguelez F. Inmigracio i mobilitat social. In: Rotger JM. Visio de Catalunya, un perspectica sociologica. Barcelona: Diputacio de Barcelona, 1988:303-320.

28 Consorci d'Informació i Documentació de Catalunya. Lloc de naixement de la poblacio: Padro municipal d'habitants de 1986. Barcelona: CIDC, 1989.

29 Brown S, Vessey M, Harris R. Social class, sexual habits and cancer of the cervix. Community Med 1984;6:281-6.

30 IARC Working Group on Evaluation of Cervical Screening Programmes. Screening for squamous cervical cancer: Programmes. Screening for squamous cervical cancer: duration of low risk after negative results of cervical cytology and its imp.

31 Izquierdo A, Viladiu P, Borràs JM, Moreno V, Catalan G. Percepcio dels causes del cancer $i$ de la seva prevencio: Analisi dels resultats d'una enquesta poblacional en dones gironines. dels resultats d'una enquesta poblacional en dones ginonines. Barcelon.

32 Chamberlain J. Reasons that some screening programmes fail to control cervical cancer. In: Hakama M, Miller AB, 
Day NE, eds. Screening for the cancer of uterine cervix. Lyons: International Agency for Research on Cancer, 1986:161-9.

33 Kaldor J, Khlat M, Parkin DM, Shiboski, Steinitz R. Loglinear models for cancer risks among migrants. Int $\mathscr{f}$ Epidemiol 1990;19:233-9.

34 Parkin DM, Steinitz R, Khlat M, Kaldor J, Katz L, Young J. Cancer in jewish migrants to Israel. Int $\mathcal{f}$ Cancer 1990 45:614-21.
35 Karjalinen S. Equity and cancer patient survival. Tampere: Acta Universitatis Temperensis (Ser A, Val 316), 1991.

36 Kogevinas M, Marmot MG, Fox AJ, Goldblatt PO. Socioeconomic differences in cancer survival. $\mathcal{f}$ Epidemiol Com munity Health 1991;45:216-9.

37 Milner PC, Watts M. Effect of socioeconomic status on survival from cervical cancer in Sheffield. I Epidemiol Community Health 1987;41:200-3. 